\begin{tabular}{cc|c}
\hline Tar. Bil. Der. & Journal of Agricultural Sciences \\
& $\begin{array}{c}\text { Dergi web sayfası: } \\
\text { www.agri.ankara.edu.tr/dergi }\end{array}$ & Journal homepage: \\
& www.agri.ankara.edu.tr/journal
\end{tabular}

\title{
An Approach to Color Change and Quality Relation in Roughages
}

\author{
Ahmet INCE ${ }^{a}$, Yasemin VURARAK \\ ${ }^{a}$ Çukurova University, Faculty of Agriculture, Department of Agricultural Machinery and Technologies Engineering, 01330, Sarıçam, Adana, \\ TURKEY \\ ${ }^{\boldsymbol{b}}$ Eastern Mediterranean Agricultural Research Institute, 01321, Yüreğir, Adana, TURKEY
}

\section{ARTICLE INFO}

Research Article DOI: 10.15832/ankutbd.538982

Corresponding Author: Ahmet İNCE, E-mail: aince@cu.edu.tr, Tel: +90 (532) 6640674

Received: 17 November 2017, Received in Revised Form: 05 January 2018, Accepted: 17 February 2018

\begin{abstract}
In this work, it was aimed to associate CIELAB Scale $\left(\mathrm{L}^{*}, \mathrm{a}^{*}, \mathrm{~b}^{*}\right)$ with some quality parameters of roughages such as $\mathrm{pH}$, crude protein $(\mathrm{CP})$ and relative feed value (RFV). To this end, five different applications; haylages unwrapped on $25^{\text {th }}, 40^{\text {th }}$ and $55^{\text {th }}$ days of fermentation, traditional silage unwrapped $55^{\text {th }}$ days of fermentation and degraded haylage were examined for vetch-triticale (Vicia sativa L. - Triticasecale wittmack) and caramba-berseem clover (Lolium multiflorum cv Caramba-Trifolium alexandrinum L.) mixtures in the study. The tests were conducted according to randomized block design with three replications for both forage mixtures. The $\Delta \mathrm{L}$ and $\Delta \mathrm{b}$ color values and $\mathrm{pH}, \mathrm{CP}, \mathrm{RFV}$ were significantly correlated in the vetch-triticale mixture. The regression coefficients $\left(\mathrm{R}^{2}\right)$ for $\Delta \mathrm{L}$ and $\Delta \mathrm{b}$ were 0.68 and 0.79 for $\mathrm{pH}, 0.40$ and 0.38 for $\mathrm{CP}, 0.63$ and 0.70 for RFV, respectively. In the mixture of the caramba - berseem clover, the regression coefficients for $\Delta \mathrm{L}$ and $\Delta \mathrm{b}$ were found to be 0.64 and 0.85 for $\mathrm{pH}, 0.14$ and 0.12 for $\mathrm{CP}, 0.28$ and 0.37 for RFV respectively. In both mixtures, the level of relation between $\Delta \mathrm{a}^{*}$ color value and quality parameters remained very low. Also, it was obtained that the best roughage in terms of RFV was haylages opened after $55^{\text {th }}$ days. Decreasing the $\mathrm{L}^{*}, \mathrm{~b}^{*}$ color values by $50 \%$ on average after fermentation can be regarded as an indication of roughage degradation and RFV reduction. From this point view, it can be possible to determine the quality change by following the colors before and after fermentation of roughage.

Keywords: Silage; Color change; Degradation; Quality; Roughage
\end{abstract}

(C) Ankara Üniversitesi Ziraat Fakültesi

\section{Introduction}

Roughages is one of the largest expenses for livestock production and generally supplied as grass, hay and silage. Recently, a large proportion of forages for livestock feeding is conserved as silage due to its several advantages. These advantages include less field and harvest losses, many crop options, high mechanization of harvesting, storage and feeding, less likelihood of weather damage during harvesting and low loss of nutrient. However, the silage quality is quite important for a profitable livestock farming.

Silage can be classified as good quality by physical characteristics like taste, smell, color and by chemical characteristics such as dry matter (DM) content, $\mathrm{pH}$ value, crude protein (CP), acid detergent fiber (ADF), and neutral detergent fiber (NDF). Good quality silage has vinegar smell, on acidic taste and a firm soft texture, leaves not 
easily rubbed, light greenish or greenish brown in color (Uygur 2009). From the point of chemical characteristics, DM content of traditional silage varied in between $70 \%-85 \%$. However, this value is around $40 \%-60 \%$ for haylage (bale silage). The $\mathrm{pH}$ value for good quality silage ranges between 3.8 and 4.0, however it can be higher (4.3-5.1) for haylage. Also, it is desirable that the $\mathrm{CP}$ value is as high as possible and the ADF and NDF values are low for pointing the silage as good quality.

Many researches have targeted to evaluate silage quality. In these studies, generally, it was aimed to determine the effects of storage period on chemical composition. It was reported that the $\mathrm{pH}$ value of silage decreased in long-term storage periods (Müller et al 2007; Shinners et al 2009; Weinberg \& Chen 2013).

There are many studies on changing $\mathrm{pH}, \mathrm{ADF}$, NDF, and RFV with fermentation duration in the literature. Shinners et al (2009) determined that the $\mathrm{pH}, \mathrm{ADF}$ and NDF values of the alfalfa silage incubated for 154 and 364 days were decreased from 5.9 to 5.13 , from $34.4 \%$ to $29.4 \%$ and from $47.1 \%$ to $38.3 \%$, respectively. Borreani et al (2008) found an opposite relationship for corn silage. The $\mathrm{pH}$, $\mathrm{ADF}$ and NDF values of the corn silage storaged for 154 and 364 days were increased from 3.74 to 3.80 , from $22.95 \%$ to $26.2 \%$ and from $44.17 \%$ to $44.92 \%$, respectively. However, they emphasized that the $\mathrm{CP}$ value decreased from $8.17 \%$ to $7.55 \%$. Müller et al (2007) were found that the CP value of meadow grass storaged for 2 and 14 months reduced from 4.88 to 4.50 . In another work done by Weber \& Kaiser (2006), it was obtained that the $\mathrm{pH}$ value of the sugar beet pulp silage has not changed for 14 and 183 days storage period. Moreover, Lee et al (2000) have determined that CP values decreased (from $10.03 \%$ to $3.04 \%$ ) and $\mathrm{ADF}$ values increased (from $37.2 \%$ to $42.92 \%$ ) according to $40,50,60,65$ days storage period for different forage species.

The extent of the effects of air ingress on bale silage is greatly important. The effect can be measure via color change. Color changing is one of the important parameters for quality of roughages
(Anonymous 1987). Also, it was reported that storage conditions affect color change in haylages and color values of the bale which is storaged at protected areas were better than the others storage conditions (Toruk et al 2009; Toruk \& Gonulol 2011). Silage color gives information about fermentation. Color evaluation of silages is considered as a physical criterion in literature and scored according to color change. In this context, relating color change to the quality parameters which are determined according to chemical analyzes is an important issue and there is limited studies focused on obtaining the relation between roughage quality and color change in the literature. The quality of roughage is foremost parameter for purchasing and adding to the feeding ration. $\mathrm{DM}, \mathrm{pH}, \mathrm{CP}$ and $\mathrm{RFV}$ can be listed as most important quality parameters. Although there are a lot of methods for determination of quality, it is another necessity for farmers to use fastest methods. Because, chemical analysis are costly and take times. In this case, affects the livestock economy negatively by increasing the cost of roughage. However,_there are methods free from chemical analysis, but the results of these methods can change relatively depends on the person who makes decision. The significant difficulties occur in determining quality of forage for farmers due to there is no standard for the estimation of roughage quality. From this point of view, the objective of this current work was to associate CIELAB Scale ( $\mathrm{L}^{*}$, $\left.a^{*}, b^{*}\right)$ with some quality parameters of roughages such as $\mathrm{pH}, \mathrm{CP}$ and RFV. Thus, practical methods can be developed to estimate the quality of forage using color change.

\section{Material and Methods}

Two roughages mixtures namely, vetch - triticale (Vicia sativa L. - Triticasecale wittmack) and caramba - berseem clover (Lolium multiflorum cv Caramba - Trifolium alexandrinum L.) were used as plant material in the experiment. Mixture rates were $70 \%$ and $30 \%$ for vetch-triticale and $50 \%$ and $50 \%$ for caramba-berseem clover, respectively. Plants were harvested at the end of the flowering stage. Materials have been storaged as haylage and traditional silage. Haylage bales were wrapped with 
$0.025 \mathrm{~mm}$ plastic film in white color as four layers. Haylage bales were opened at the days of 25,40 and 55 and the color changing was compared with traditional and degraded silage in terms of $\mathrm{pH}, \mathrm{CP}$ and RFV.

The silage samples color was examined by using Minolta CR-100 Chromameter color measurement device. In the CIE $1976\left(\mathrm{~L}^{*}, \mathrm{a}^{*}, \mathrm{~b}^{*}\right)$ color space, abbreviated CIELAB, the lightness coefficient, $\mathrm{L}^{*}$, ranges from black $=0$ to white $=100$ and is roughly analogous to the Munsell value scale times 10. For any measured color of lightness, $\mathrm{L}_{\mathrm{i}}^{*}$, the coordinates $\left(\mathrm{a}^{*}, \mathrm{~b}^{*}\right)$ locate the color on a rectangular-coordinate grid perpendicular to the $\mathrm{L}^{*}$ axis at $\mathrm{L}_{\mathrm{i}}^{*}$. The color at the grid origin $\left(a^{*}=0, b^{*}=0\right)$ is achromatic (gray). On the horizontal axis, positive $\mathrm{a}^{*}$ indicates o hue of red-purple; negative $a^{*}$, of bluish-green. On the vertical axis, positive $b^{*}$ indicates yellow and negative $b^{*}$ blue (Figure 1) (McGuire 1992).

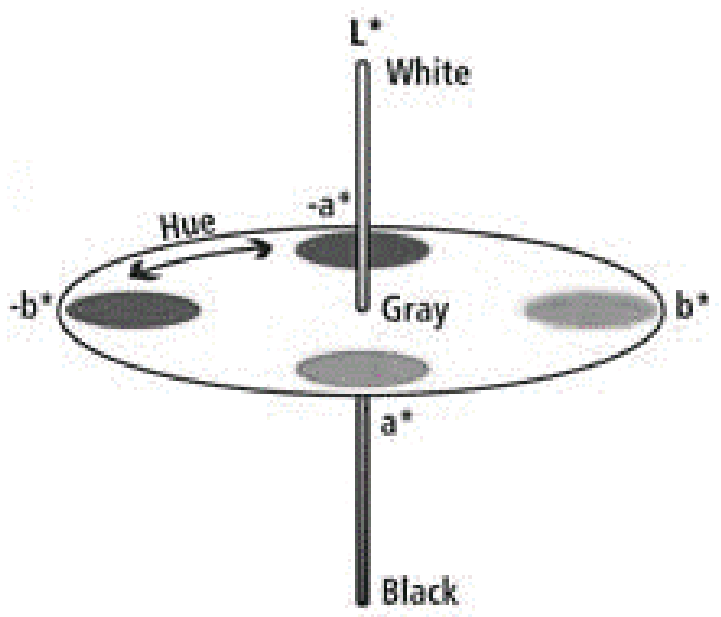

Figure 1- CIELAB color space

For determination of color changing, material color was measured before storage and after unwrapped and calculated by subtracting second (2) measurement from first one (1) (Snell et al 2002).

$$
\begin{aligned}
& \Delta L=L_{1}^{*}-L_{2}^{*} \\
& \Delta a=a_{1}^{*}-a_{2}^{*} \\
& \Delta b=b_{1}^{*}-b_{2}^{*}
\end{aligned}
$$

The quality of the material was evaluated in terms of $\mathrm{pH}, \mathrm{CP}, \mathrm{ADF}, \mathrm{NDF}$ and RFV. Nitrogen (N) content was measured using the Kjeldahl Method. The $\mathrm{pH}$ values of plants were obtained as reported by Chen et al (1994). The CP was calculated as $\mathrm{N}$ $\times 6.25$ (AOAC 1990). The NDF and ADF were determined as suggested Van Soest et al (1991) by using ANKOM fiber analyzer. The RFV was calculated by using equation given below (Mayouf \& Arbouche 2014).

$R F V=(88.9-(0.779 x A D F \%)) x((120 / N D F \%) / 1.29)$

To investigate the effect of color changing on quality parameters, the tests were conducted according to randomized block design with three replications for both forage mixtures. Five different applications were tested in the study (Table 1). The Jump 7 statistical program was used in evaluating the data and groupings were made according to LSD

\begin{tabular}{|c|c|}
\hline Abbreviation & Applications \\
\hline H1 & $\begin{array}{l}\text { Haylage, unwrapped on the } 25^{\text {th }} \text { day of } \\
\text { the fermentation }\end{array}$ \\
\hline $\mathrm{H} 2$ & $\begin{array}{l}\text { Haylage, unwrapped on the } 40^{\text {th }} \text { day of } \\
\text { the fermentation }\end{array}$ \\
\hline $\mathrm{H} 3$ & $\begin{array}{l}\text { Haylage, unwrapped on the } 55^{\text {th }} \text { day of } \\
\text { the fermentation }\end{array}$ \\
\hline TS & $\begin{array}{l}\text { Traditional silage, opened on the } 55^{\text {th }} \\
\text { day of the fermentation }\end{array}$ \\
\hline DH & Degraded haylage \\
\hline
\end{tabular}
(Yurtsever 1984).

Table 1- Applications tested in the study

\section{Results and Discussion}

A review of Table 2 shows that the color values of both mixtures did not differ statically before wrapping but they were found significant at $1 \%$ level after opening.

It is desirable that the color values after opening as silage quality indicators do not differ much from the initial color values. Table 3 presents the color changing values according to applications. When the color values are examined after both mixtures 
Table 2- Coefficients of variation for according to mixtures

\begin{tabular}{cllllll}
\hline \multirow{2}{*}{ Parameters } & \multicolumn{2}{l}{ Vetch-Triticale } & \multicolumn{4}{l}{ Caramba-Berseem Clover } \\
\cline { 2 - 7 } & Pvalue & $L S D_{(0.05)}$ & $C V(\%)$ & Pvalue & LSD & \\
\hline $\mathrm{L}_{1}{ }^{*}$ & $0.05)$ & $C V(\%)$ \\
$\mathrm{a}_{1}{ }^{*}$ & $0.9216^{\mathrm{ns}}$ & - & 5.08 & $0.2893^{\mathrm{ns}}$ & - & 2.41 \\
$\mathrm{~b}_{1}{ }^{*}$ & - & 13.0 & $0.3040^{\mathrm{ns}}$ & - & 8.06 \\
$\mathrm{~L}_{2}{ }^{*}$ & $0.1507^{\mathrm{ns}}$ & - & 7.37 & $0.8241^{\mathrm{ns}}$ & - & 8.73 \\
$\mathrm{a}_{2}{ }^{*}$ & $0.00001^{* *}$ & 4.20 & 5.34 & $0.0010^{* *}$ & 6.15 & 7.79 \\
$\mathrm{~b}_{2}{ }^{*}$ & $<0.0001^{* *}$ & 1.45 & 23.24 & $<.0001^{* *}$ & 0.53 & 6.52 \\
\hline
\end{tabular}

${ }^{*},{ }^{* *},{ }^{\text {ns }}$ significant at the levels of $5 \%, 1 \%$, and not significant respectively

are opened, it was determined that the $\mathrm{L}^{*}$ value before wrapping was 52.7 for the vetch-triticale mixture and 50.2 for the caramba-berseem clover mixture on average for silage and haylage ( $\mathrm{H} 1$, $\mathrm{H} 2, \mathrm{H} 3$ and TS). It can be seen that the best color values in terms of $\mathrm{L}^{*}$ are obtained from the $\mathrm{H} 3$ application in the study. It was determined that the $\mathrm{L}^{*}$ values decreased in both mixtures when comparing $\mathrm{H} 3$ and TS applications. This value decreased from 47.70 to 43.56 in the case of the vetch-triticale mixture and from 42.50 to 49.85 in the case of the caramba-berseem clover mixture. This is an indication that the storage conditions affect the $L^{*}$ value. After opening, these values decreased 45.0 and 44.5 in average for the vetchtriticale mixture and the caramba-berseem clover mixture, respectively. The $\mathrm{L}^{*}$ value was found to be 28.5 for the vetch-triticale mixture and 31.4 for the caramba-berseem clover mixture, on average, for the degraded haylage (DH) samples. It was found that the average $\mathrm{L}^{*}$ value of the degraded roughage decreased by $45.6 \%$ in the vetchtriticale mixture and by $37.6 \%$ in the mixture of caramba-berseem clover according to the initial $L^{*}$ value. That means, the degraded samples lost their brightness compared to the other roughage samples. When the $\mathrm{b}^{*}$ (yellow-blue) value before wrapping was examined, it was determined that this value was 23.3 in the vetch - triticale mixture and 21.0 in the caramba-berseem clover mixture. After opening the silage and haylage, this value increased slightly, reaching 23.9 for the vetch- triticale mixture and 21.8 for the caramba-berseem clover mixture. This situation can be interpreted as an indication that the $b^{*}$ color value is not affected by the storage duration. In the degraded specimens, $b^{*}$ decreased by an average of $50 \%$ and it was found to be 12.1 and 13.1 for the vetchtriticale mixture and the caramba-berseem clover mixture, respectively. The $\mathrm{a}^{*}$ (red-green) value was found as 11.4 for the vetch-triticale mixture and 11.9 in the caramba-berseem clover before wrapping, then decreased to 4.1 and 4.7 after opening, respectively. In deteriorated samples, this value decreased to 2.2 and 2.9 , respectively. Snell et al (2003) found a relation between applications and color values of $\mathrm{L}^{*}$ and $\mathrm{a}^{*}$. Ball et al (2017) also emphasized that a bright green color can be an indicator of storage conditions which shows good protection during storage. However, statistical mean value comparison regarding the $b^{*}$ values did not result in any significant difference. This study also gave similar results.

Table 4 illustrates that in the vetch-triticale mixture, all applications significant at $1 \%$ level on $\mathrm{pH}, \mathrm{ADF}, \mathrm{NDF}, \mathrm{CP}$ and RFV. In the case of the mixture of caramba-berseem clover, the applications have a significant effect on $\mathrm{pH}, \mathrm{ADF}, \mathrm{CP}$ at $1 \%$ level, but at 5\% level on RFV and no effect on NDF.

It was determined that the $\mathrm{pH}$ value was highest in deteriorated haylage and the lowest in traditional silage. In both mixtures, it was obtained that the best application among haylages was roughage which was left for 55 days fermentation (H3). In terms of 
Table 3- Color changing values according to applications

\begin{tabular}{lllllll}
\hline Mixture & & $H 1$ & $H 2$ & $H 3$ & $T S$ & $D H$ \\
\hline & $\mathrm{L}_{1}{ }^{*}$ & 52.70 & 50.05 & 54.85 & 52.43 & 53.46 \\
& $\mathrm{a}_{1}{ }^{*}$ & 11.35 & 11.40 & 12.00 & 11.40 & 10.86 \\
Vetch- triticale & $\mathrm{b}_{1}{ }^{*}$ & 24.55 & 24.65 & 23.85 & 22.83 & 21.03 \\
& $\mathrm{~L}_{2}{ }^{*}$ & $46.30^{\mathrm{ab}}$ & $42.60^{\mathrm{b}}$ & $47.70^{\mathrm{a}}$ & $43.56^{\mathrm{ab}}$ & $28.56^{\mathrm{c}}$ \\
& $\mathrm{a}_{2}{ }^{*}$ & $6.05^{\mathrm{a}}$ & $2.65^{\mathrm{c}}$ & $3.50^{\mathrm{bc}}$ & $4.43^{\mathrm{ab}}$ & $2.26^{\mathrm{c}}$ \\
& $\mathrm{b}_{2}{ }^{*}$ & $24.75^{\mathrm{a}}$ & $22.10^{\mathrm{b}}$ & $24.75^{\mathrm{a}}$ & $24.00^{\mathrm{ab}}$ & $12.10^{\mathrm{c}}$ \\
\cline { 2 - 6 } & $\mathrm{L}_{1}{ }^{*}$ & 50.25 & 50.30 & 49.70 & 51.53 & 49.25 \\
Caramba- & $\mathrm{a}_{1}{ }^{*}$ & 10.90 & 11.65 & 12.50 & 12.46 & 12.10 \\
& $\mathrm{~b}_{1}{ }^{*}$ & 20.60 & 21.90 & 20.60 & 21.63 & 20.60 \\
& $\mathrm{~L}_{2}{ }^{*}$ & $39.35^{\mathrm{c}}$ & $47.55^{\mathrm{ab}}$ & $49.50^{\mathrm{a}}$ & $41.83^{\mathrm{bc}}$ & $31.40^{\mathrm{d}}$ \\
& $\mathrm{a}_{2}{ }^{*}$ & $4.70^{\mathrm{b}}$ & $4.10^{\mathrm{c}}$ & $4.50^{\mathrm{bc}}$ & $5.56^{\mathrm{a}}$ & $2.90^{\mathrm{d}}$ \\
& $\mathrm{b}_{2}{ }^{*}$ & $19.35^{\mathrm{b}}$ & $22.05^{\mathrm{ab}}$ & $24.65^{\mathrm{a}}$ & $21.26^{\mathrm{b}}$ & $13.10^{\mathrm{c}}$ \\
\hline
\end{tabular}

Means in each column with the same letters are not significantly different $(\mathrm{P}<0.05)$

Table 4- Coefficients of variation $\mathrm{pH}, \mathrm{ADF}, \mathrm{NDF}, \mathrm{CP}$ and RFV according to mixtures

\begin{tabular}{lllllll}
\hline \multirow{2}{*}{ Parameters } & \multicolumn{2}{l}{ Vetch-Triticale } & \multicolumn{4}{c}{ Caramba-Berseem Clover } \\
\cline { 2 - 7 } & Pvalue & $L S D_{(0.05)}$ & $C V(\%)$ & Pvalue & LSD & \\
\hline $\mathrm{pH}$ & $<.0001^{* *}$ & 0.12 & 1.34 & $<0.0001^{* *}$ & 0.41 & 4.26 \\
$\mathrm{ADF}$ & $0.0003^{* *}$ & 4.11 & 4.58 & $0.0071^{* *}$ & 6.54 & 7.63 \\
$\mathrm{NDF}$ & $0.0014^{* *}$ & 5.67 & 5.34 & $0.3322^{\mathrm{ns}}$ & - & 4.74 \\
$\mathrm{CP}$ & $0.0005^{* *}$ & 0.89 & 5.73 & $0.0031^{* *}$ & 0.93 & 6.39 \\
$\mathrm{RFV}$ & $0.0012^{* *}$ & 14.55 & 8.25 & $0.0372^{*}$ & 15.05 & 8.65 \\
\hline
\end{tabular}

***, ns significant at the levels of $5 \%, 1 \%$, and not significant respectively

$\mathrm{ADF}$, the $\mathrm{H} 3$ application has the lowest value in both mixtures, and this value was highest in the degraded haylage. Shinners et al (2009) also obtained similar results in their studies. It can be said that the fermentation period has the positive effect on ADF and $\mathrm{pH}$. This may be explained by the increase in the amount of sugar used by Lactic Acid Bacteria in the length of time. When the HP values were compared according to the applications, it was determined that the HP ratio in the caramba-berseem clover was not affected statistically by the fermentation period and remained in the same group. However, the $\mathrm{CP}$ ratio for the conventional silage remained low compared to haylages. In the vetch-triticale mixture, the $\mathrm{CP}$ value was slightly increased with the fermentation time. In both mixtures, the $\mathrm{CP}$ value was lower in the degraded silage than the other applications (Table 5).

The relationship between color values $(\Delta \mathrm{L}$, $\Delta \mathrm{a}, \Delta \mathrm{b})$ and quality parameters ( $\mathrm{pH}, \mathrm{CP}$ and RFV) for both mixtures was determined and graphically presented in Figure 2, 3 and 4. It was determined that $\Delta \mathrm{L}$ and $\Delta \mathrm{b}$ color values and $\mathrm{pH}, \mathrm{CP}, \mathrm{RFV}$ were significantly correlated in the vetch-triticale mixture. The regression coefficients $\left(\mathrm{R}^{2}\right)$ for $\Delta \mathrm{L}$ and $\Delta \mathrm{b}$ were 0.68 and 0.79 for $\mathrm{pH}$ and 0.63 and 0.70 for RFV, respectively. However, for CP these coefficients were calculated lower as 0.40 and 
Table 5- Quality values according to applications

\begin{tabular}{lllllll}
\hline Parameters & & $H 1$ & $H 2$ & $H 3$ & $T S$ & $H D$ \\
\hline \multirow{5}{*}{ Vetch-triticale } & $\mathrm{pH}$ & $5.05^{\mathrm{b}}$ & $4.79^{\mathrm{c}}$ & $4.49^{\mathrm{d}}$ & $3.46^{\mathrm{e}}$ & $7.18^{\mathrm{a}}$ \\
& $\mathrm{ADF}(\%)$ & $46.70 \mathrm{~b}^{\mathrm{c}}$ & $49.50^{\mathrm{b}}$ & $41.35^{\mathrm{d}}$ & $44.06^{\mathrm{cd}}$ & $56.36^{\mathrm{a}}$ \\
& $\mathrm{NDF}(\%)$ & $56.40^{\mathrm{b}}$ & $54.60^{\mathrm{b}}$ & $52.35^{\mathrm{b}}$ & $51.36^{\mathrm{b}}$ & $67.03^{\mathrm{a}}$ \\
& $\mathrm{CP}(\%)$ & $7.90^{\mathrm{bc}}$ & $8.80^{\mathrm{b}}$ & $10.16^{\mathrm{a}}$ & $8.34^{\mathrm{bc}}$ & $7.01^{\mathrm{c}}$ \\
& $\mathrm{RFV}$ & $93.14^{\mathrm{b}}$ & $92.59^{\mathrm{b}}$ & $108.34^{\mathrm{a}}$ & $106.83^{\mathrm{ab}}$ & $67.21^{\mathrm{c}}$ \\
\hline \multirow{5}{*}{ Caramba- } & $\mathrm{pH}$ & $5.18^{\mathrm{b}}$ & $4.96^{\mathrm{bc}}$ & $4.25^{\mathrm{d}}$ & $4.55^{\mathrm{cd}}$ & $6.60^{\mathrm{a}}$ \\
& $\mathrm{ADF}(\%)$ & $42.30^{\mathrm{b}}$ & $43.50^{\mathrm{b}}$ & $42.10^{\mathrm{b}}$ & $45.16^{\mathrm{b}}$ & $55.60^{\mathrm{a}}$ \\
& $\mathrm{NDF}(\%)$ & 57.50 & 56.45 & 56.00 & 59.53 & 60.15 \\
& $\mathrm{CP}(\%)$ & $8.62^{\mathrm{a}}$ & $8.47^{\mathrm{a}}$ & $8.07^{\mathrm{a}}$ & $6.94^{\mathrm{b}}$ & $6.60^{\mathrm{b}}$ \\
& $\mathrm{RFV}$ & $97.30^{\mathrm{a}}$ & $97.42^{\mathrm{a}}$ & $100.16^{\mathrm{a}}$ & $90.52^{\mathrm{ab}}$ & $76.38^{\mathrm{b}}$ \\
\hline
\end{tabular}

Means in each column with the same letters are not significantly different $(\mathrm{P}<0.05)$

0.38 , respectively. In the mixture of the carambaberseem clover, the regression coefficients for $\Delta \mathrm{L}$ and $\Delta \mathrm{b}$ were found to be 0.64 and 0.85 for $\mathrm{pH}, 0.14$ and 0.12 for $\mathrm{CP}, 0.28$ and 0.37 for RFV respectively. In both mixtures, it was obtained that $\mathrm{R}^{2}$ which was calculated to determine the level of relation between $\Delta \mathrm{a}$ color value and quality parameters remained very low. It was found that the values of $\Delta \mathrm{L}$ and $\Delta \mathrm{b}$ were significantly related to $\mathrm{pH}$ in both mixtures, while the value of $\mathrm{L}^{*}$ before wrapping decreased gradually after opening, while $\mathrm{pH}$ value increased and RFV decreased. The similar situation was obtained for $b^{*}$ color value. It has been determined that the best roughage in terms of RFV was obtained from haylages opened after 55 days (H3). In this period the $\Delta \mathrm{L}$ and $\Delta \mathrm{b}$ values for the vetch-triticale mixture were 7.15-0.9 and 0.24.05 for the mixture of caramba-berseem clover, respectively. This shows that when the difference between the values of $\mathrm{L}^{*}$ and $\mathrm{b}^{*}$ before and after fermentation approaches the value of 0 , RFV increases.
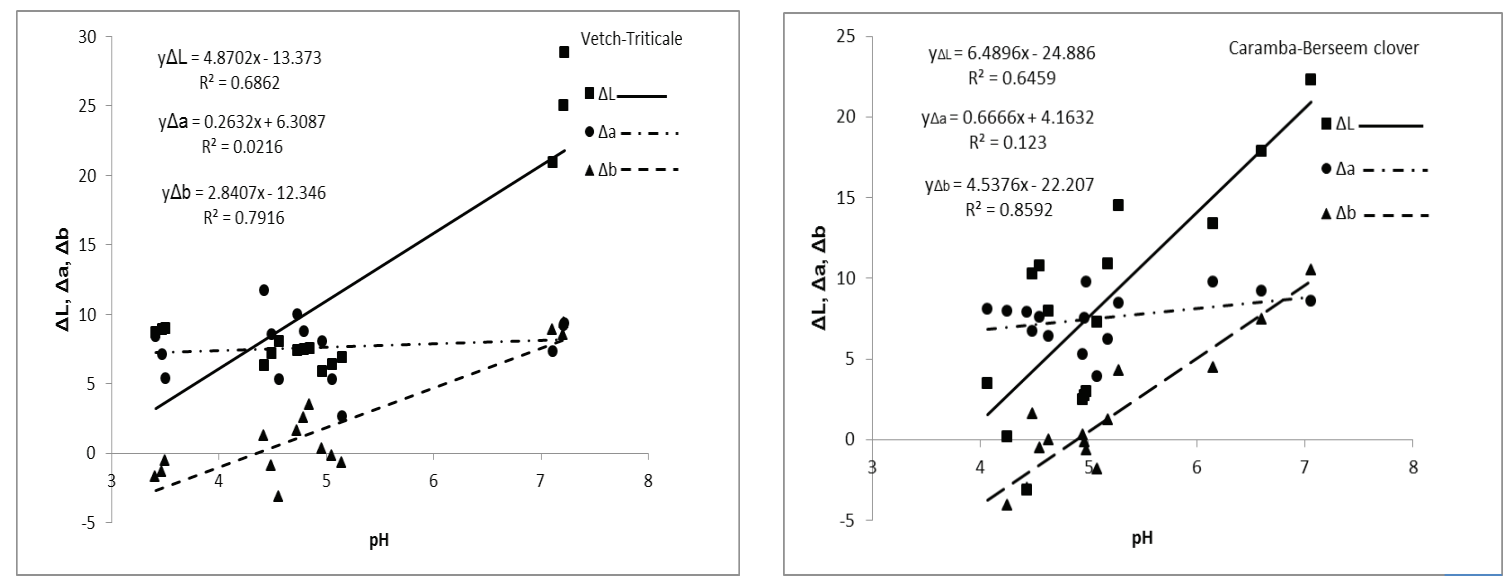

Figure 2- Relationship between color changes and pH 


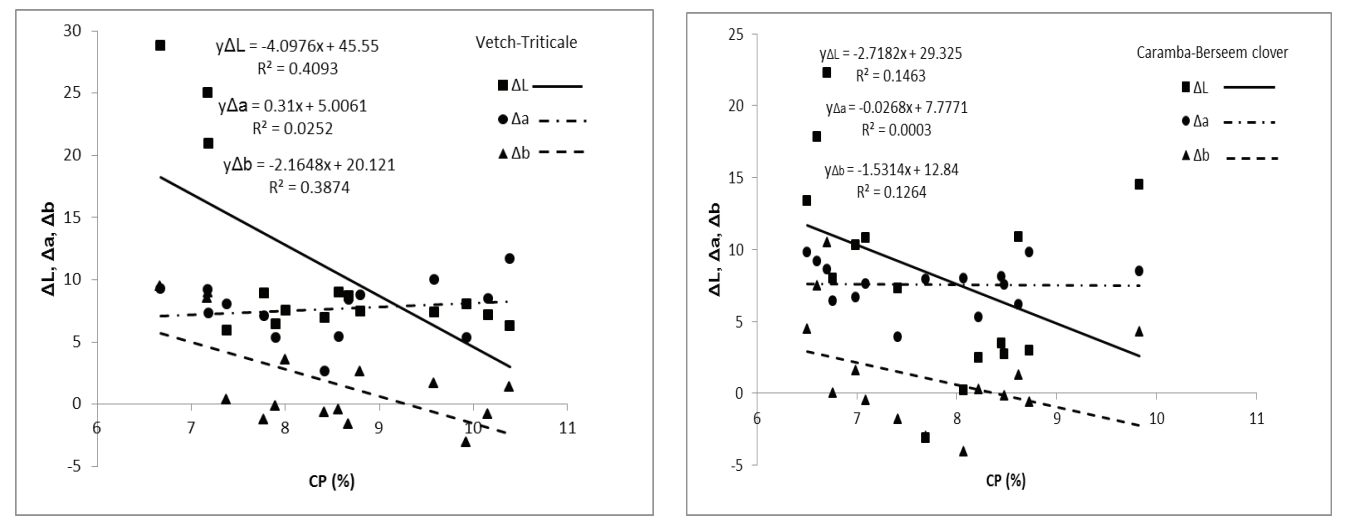

Figure 3- Relationship between color changes and CP
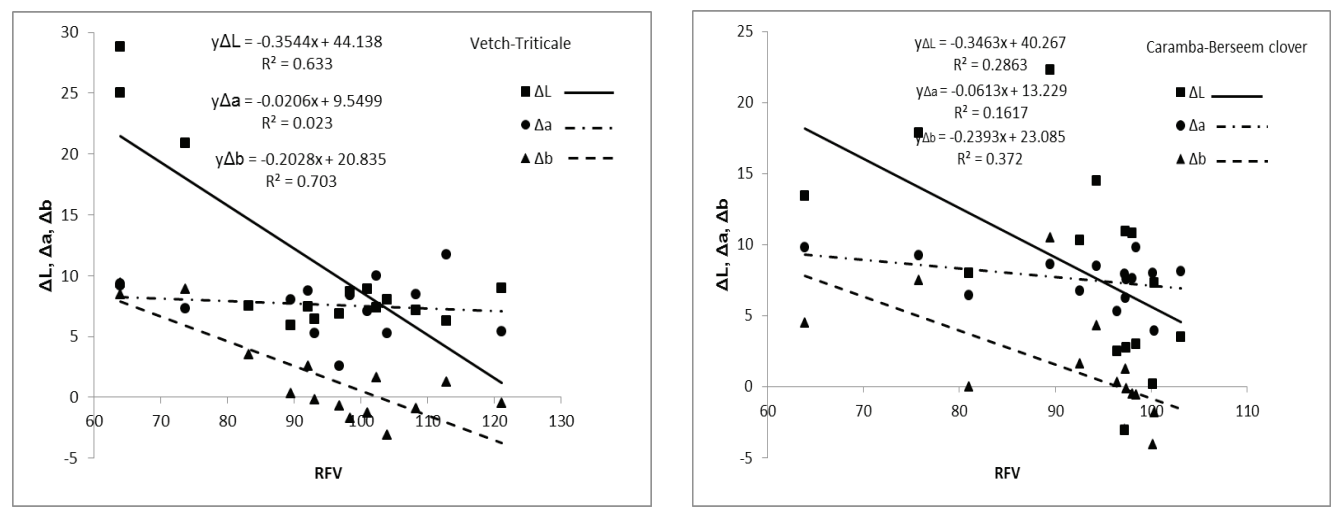

Figure 4- Relationship between color changes and RFV

\section{Conclusions}

In the study, some quality criteria were tried to be associated with the change of $L^{*}, a^{*}, b^{*}$ color values in roughage. It has been determined that these values have an acceptable correlation with $\mathrm{pH}$ and RFV in both mixtures. Decreasing the $\mathrm{L}^{*}, \mathrm{~b}^{*}$ color values by $50 \%$ on average after fermentation can be regarded as an indication of roughage degradation and RFV reduction. From this point view, it can be possible to determine the quality change by following the colors before and after fermentation of roughage. It can be said that this study is important because of showing possibility to have information about the quality of roughages by following the color change. Further, similar studies can be performed on other roughage to obtain color change scales, which can be used for quality estimation.

\begin{tabular}{|ll|}
\hline \multicolumn{2}{|l|}{ Abbreviations and Symbols } \\
\hline CIELAB $\left(\mathrm{L}^{*}, \mathrm{a}^{*}, \mathrm{~b}^{*}\right)$ & Color space \\
$\mathrm{pH}$ & Potential of hydrogen \\
$\mathrm{CP}$ & Crude protein, \% \\
$\mathrm{RFV}$ & Relative feed value \\
$\Delta \mathrm{L}$ & Color change of $\mathrm{L}^{*}$ \\
$\Delta \mathrm{b}$ & Color change of $\mathrm{b}^{*}$ \\
$\Delta \mathrm{a}$ & Color change of $\mathrm{a}^{*}$ \\
$\mathrm{~L}^{*}$ & Lightness \\
$\mathrm{a}^{*}$ & Red-green \\
$\mathrm{b}^{*}$ & Yellow-blue \\
$\mathrm{DM}$ & Dry matter, \% \\
$\mathrm{ADF}$ & Acid detergent fiber, $\%$ \\
$\mathrm{NDF}$ & Neutral detergent fiber, $\%$ \\
$\mathrm{~N}$ & Nitrogen \\
$\mathrm{CV}$ & Coefficient of variation, $\%$ \\
$\mathrm{P}$ & Probability \\
$\mathrm{LSD}$ & Least significant difference \\
\hline
\end{tabular}




\section{References}

Anonymous (1987). Bewertung von grünfutter, silage und heu, merkblatt, No: 224, DLG-Verlag, Deutschland

AOAC (1990). Association of official analytical chemists. Official method of analysis. $15^{\text {th }}$ Ed. Washington, DC. USA. pp. 66-88

Ball D, Collins M, Lacefield G, Martin N, Mertens D, Olson K, Putnam D, Undersander D \& Wolf M (2017). Understanding forage quality. http://www.georgiaforages. com/events/GS13/01/understandingforagequality.pdf (Access date: November 02, 2017)

Borreani G, Chion A R, Piano S, Ranghino F \& Tabocco E (2008). A preliminary study on new biodegradable films to cover silages. Proceeding of The $23^{\text {th }}$ General Meeting of The Europa Grassland Federation. Germany, Grassland Science in Europa 15: 202-204

Chen J, Stokes M R \& Wallace C R (1994). Effects of enzyme-inoculant systems on preservation and nutritive value of haycrop and corn silages. Jurnal of Dairy Science 77: 501-512

Lee M, Hwang S \& Chiou P W (2000). Metabolizable energy of roughale in Taiwan. Small Ruminant Research Elsevier 36(2000): 251-259

Mayouf R \& Arbouche F (2014). Chemical composition and relative feed value of three mediterranean fodder shrubs. African Journal of Agricultural Research 9(8): 746-749

McGuire R G (1992). Reporting of objective color measurements. HortScience 27(12): 1254-1255

Müller C E, Pauly T M \& Uden P (2007). Storage of small bale silage and haylage - influence of storage period on fermentation variables and microbial composition. Grass and Forage Science (62): 274-283

Shinners K J, Huenink B M, Muck R E \& Albrecht K A (2009). Storage characteristics of large round and square alfalfa bales: low-moisture wrapped bales. American Society of Agricultural and Biological Engineers ISSN 0001-2351. 52(2): 401-407
Snell H G J, Oberndorfer C, Lücke W \& Van den Weghe H F A (2002). Effects of polyethylene film parameters: color and thickness, on ensiling conditions and silage quality of chopped maize, as investigated under ambient conditions and in a test apparatus. Grass and Forage Science, 57: 342-350

Snell H G J, Obemdorfer C, Lücke W \& Van den Weghe H F A (2003). Effects of polyethylene colour and thickness on grass silage quality. Grass and Forage Science 58: 239-248

Toruk F \& Gonulol E (2011). Effects of particle length on alfalfa baled silage quality and color under different storage conditions. Bulgarian Journal of Agricultural Science 17(4): 451-455

Toruk F, Gonulol E \& Ulger P (2009). Color changes of bale silage under different storage conditions. Journal of Agricultural Machinery Science 5(2): 211-216

Uygur M (2009). Silaj kalitesinin fiziksel ve kimyasal yöntemlerle belirlenmesi. Ege Tarımsal Araştırma Enstitüsü Yayınları, Çiftçi broşürü, No: 127, İzmir

Van Soest P J, Robertson J D \& Lew1s B A (1991). Methods for dietry fibre, neutral detergent fibre and non-starch polysaccharides in relation to animal nutrition. Journal of Dairy Science 74: 3583-3597

Weber U \& Kaiser E (2006). Improvement of aerobic stability of pressed sugar beet pulp silage, made in large plastic silage bags, depending on ensiling period and silage additive. $12^{\text {th }}$ International Symposium Forage Conservation. Brno, Czech Rep., April 3-5, pp. $175-177$

Weinberg Z G \& Chen Y (2013). Effects of storage period on the composition of whole crop wheat and corn silages. Animal Feed Science and Technology 185: 196-200

Yurtsever N (1984). Deneysel istatistik metotları. Tarım Orman ve Köyişleri Bakanlığı Köy Hizmetleri Genel Müdürlügü. Toprak ve Gübre Araştırma Enstitüsü Müdürlügü Yayınları Genel Yayın No: 121. Teknik Yayın No: 56, Ankara 